Research.

\title{
Analysis of yogurt raw materials control using MRP method at PT. Heavenly Nutrition Indonesia
}

\author{
Yustiana Wardhani ${ }^{1^{*}}$, Ikbal Indrawan ${ }^{2}$ \\ ${ }^{1 *}$ Department of Management, Economic College of Binaniaga, Bogor, Indonesia \\ ${ }^{2}$ Department of Management, Economic College of Binaniaga, Bogor, Indonesia \\ yustiana.wardhani@yahoo.com (Y.Wardhani), qbibe632@yahoo.com (I. Indrawan) \\ * Corresponding author
}

Received: April 28, 2019; Accepted: May 22, 2019; Published: June 30, 2019

To cite this article: Wardhani, Yustiana, Ikbal Indrawan. 2019. Analysis of yogurt raw materials control using MRP method at PT. Heavenly Nutrition Indonesia. The Management Journal of BINANIAGA. 4 (1): 11-22. doi:

\begin{abstract}
The aim of this research is going to find out the inventory level of yogurt raw materials at PT HNI. Running MRP method is to make sure that the production process is working good which can increase the efficiency of yogurt raw materials control at PT HNI. Result of the research has indicated that the method of calculation is based on the average of the last three months period, and also based on the forecast coming from Marketing Department, though some products calculated are based on the historical periode (the previous year), nevertheless the forecast of raw materials purchase is obtained.
\end{abstract}

Keywords: MRP Method

\section{Introduction}

\section{Background}

Basically the objective of any kind of company is getting profit. Reaching that objective, a company should have managed its business very well and economical cost, so that it can meet the customers expectation and obtain their trust which is one of the crucial capital for the company. Having got the consumers trustworthy explaining that the products manufactured are usable.

A method to control the inventory is Material Requirement Planning (MRP). MRP is a technique approach to improve the productivity of a company by scheduling the raw materials and other components requirement to ensure that the company has received a minimum requirement of dependent components and to guarantee that the finished products can be manufactured accordingly.

Material Requirement Planning is also a mechanism concept to define the quantity of materials required and when the materials arrived. MRP system is figuring out the quantity of raw materials ordered which is in line with the production requirement by calculating the inventory cost and purchasing cost.

An industrial company that is manufacturing finished goods such as PT Heavenly Nutrition Indonesia (PT HNI) producing food and Yogurt drink starting from raw materials going thru work in process and finally producing the finished products has to make sure that the production process is well managed, however a proper production management controlling the materials is required to ensure that all the materials needed are ready. 


\section{Problems Design}

After studying the background described above, the writer tends to write a scientific study about the following problems:

a. To what extent is the inventory applying MRP method available?

b. How proper is PT Heavenly Nutrition Indonesia applying the MRP method?

\section{Objectives}

This research aims to:

a. Figure out to what extent of raw materials stocks are available for yogurt products at PT HNI.

b. Find out that MRP method application has provided a proper production process and increased the production efficiency upon yogurt raw materials at PT HNI.

\section{Library Review}

\section{Operation Management}

Operation management consists of two words, management and operation. Management means a particular process consisting of planning, organizing, directing and controlling that should have to done reaching the targets using all human resources and other recources required.

According to Jay Heizer and Barry Rander (2010:4), operation management is a chain of activities producing the value of goods and services which has changed the input to the output.

Referring to Jay Heizer and Barry Render (2009:51), the companies can reach their goals thru the following three efforts:

a. Competitiveness in the differentiation.

Differentiation relates to a unique presentation and it is beyond physical characteristics and service attribute achievement covering the products or services influencing the value of the consumers expectation.

b. Competitiveness in Cost / price.

Low cost management means it has met the maximum value of the customers expectation. But it requires ten evaluations of the operation management decision to work hard decreasing the costs or price but meeting the customers expectation. Low costs strategy does not mean that the quality of the products is becoming low.

c. Competitiveness in Responses

All the values are related to the development and goods delivery which is on time, reliable scheduled and flexible job performance.

Operation management is covering all the activities focusing to the optimal processing applying production factors; human resources, machineries, equipments, raw materials, and other production factors in the transformation of production process such as goods and services.

\section{Stock / Inventory}

In general, the inventory/ stock eases or speeds up the operation process in a company which is continous producing the goods and the distribution of the goods reaching the customers or consumers. 

as follows:

R. Agus Sartono (2010:443) desribed that the meaning of stocks/ inventory is

"Inventory is the stocks of materials, parts and other materials in the process which are available in the company to perform the production process, finished goods or the products manufactured to supply the demands of the customers or related component at any time" as follows:

Mamduh M. Hanafi (2010:87) describing that the definition of stock inventory is

"Stock inventory is usually covering some kind of stock inventory such as raw materials, finished goods. Raw materials is the materials to be used in the production to produce the finished goods. Work in process is the product which has not completed yet to be the finished goods. Finished goods is the products which are ready to be sold".

Therefore, stock inventory can be divided and classified according to their type and position in the production processing:

a. Raw materials stock is tangible stocks to be produced.

b. Supplies stock is the stock of materials needed in the production process of the product but it is not a part of the component of finished goods.

c. Work in process stock is the stock of the goods which has been manufactured in a factory but it still needs further process to produce it as finished goods.

d. Finished goods stock is the stock of goods which have been produced completely thru the raw materials processing, work in process, and finally finished goods that are ready to be sent to the consumers.

Based on the statements above, it can be concluded that stock inventory is the resources of stock which are not consumed in the production process, distribution and consumption, they are the assets of the company either raw materials, supllies materials, work in process and finished goods.

\section{Material Requirement Planning (MRP)}

a. MRP definition

Referring to Heizer and Render (2011) MRP is a requistion model using the list of materials, expected arrival according to the master production schedule which are going to be used in the production of the products.

Referring to Gasperz (2012) Material Requirement Planning (MRP) defined as a kind of technique or set of systematic procedure to define the quantity and time table of the materials due to the controlling of the process of materials required upon the dependent demand items.

MRP is a technique to plan and to control the dependent demand items at the top level. MRP was found by Joseph Orlicky at J.I.Case company in 1960 for the first time.

Some experts have defined the MRP as follows":

According to Eddy Herjanto (2010: 275) in his books of Operation Management defined: MRP is a concept in the production management describing a proper planning of the materials required in the production process.

The definition above has described that MRP is a particular system designed in the production management describing a proper way to plan the raw materials required in the production process so that all the materials required are well managed and are in compliance with the applicable forecast. 
b. MRP components

An effective application of MRP model is obliged to follow some requirements to be understood correctly, as follows:

1) Master Production Schedule

2) Specification of Bill of Materials.

\section{Bill of Materials Drawing}

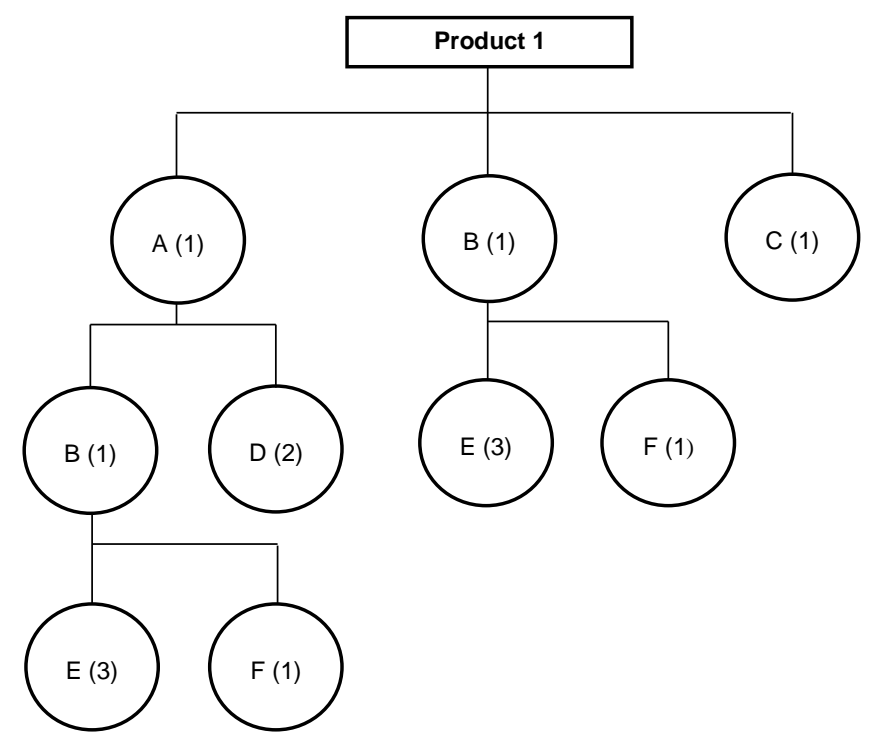

It is assumed that the company will manufacture Product 1 (P1) for 1 unit, then, the calculation should have to be done as the following:

Component $\mathrm{A}:: 1 \mathrm{x}$ total $\mathrm{P} 1=1 \times 1=1$

Component $B:(1 \times$ total $\mathrm{PI})+(1 \times$ total $A)=(1 \times 1)+(1 \times 1)=2$

Component $\mathrm{C}: 1 \times$ total $\mathrm{P}=1 \times 1=1$

Component $\mathrm{D}: 2 \times$ total $\mathrm{P} 1=2 \times 1=2$

Component $\mathrm{E}:(3 \times$ total $\mathrm{B})+(3 \times$ total $\mathrm{B})=(3 \times 1)+(3 \times 1)=6$

Component $\mathrm{F}:(1 \mathrm{x}$ total $\mathrm{B})+(1 \mathrm{x}$ total $\mathrm{B})=(1 \times 1)+(1 \times 1)=2$

The equations above have described that Product $\mathrm{P} 1$ (P1) production calculating that for one unit $P 1$ requires 1 unit $A, 1$ unit $B$ and 1 unit $C$, each unit of $A$ requires 1 unit $B$ and 2 units $D$, and for one unit $B$ requires 3 units $E$ and 1 unit $F$, nevertheless the requisition of $A, B, C, D, E$ and $F$ are depending on $P 1$. So that, producing $P 1$ requires 1 unit $A, 2$ units $B, 1$ unit $C, 2$ units $D, 6$ units $E$ and 2 units F.

Output of MRP has depicted the ability and characteristic of MRP itself, as the following:

1) Planned Order Schedule

2) Order Release Report

3) Changes to Planning Orders

4) Performance Report

5) Lead time is a purchasing system of time delivery of materials ordered. 


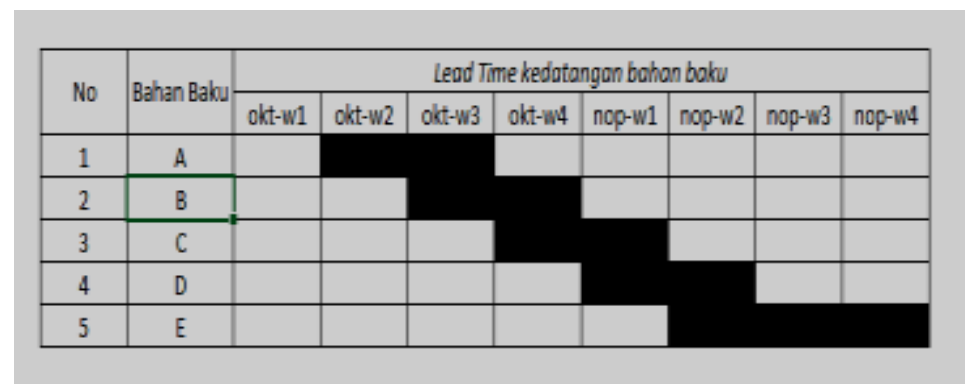

c. MRP objectives

1) Stock minimized

2) Reducing risks due to the late production or late delivery.

3) Realistic commitment.

4) Increasing the efficiency

d. MRP limits

MRP is not providing a detail schedule. But, MRP is describing the job that should have to be completed in a week, however, it is not decribing any details of when it starts and when it finishes.

e. MRP form

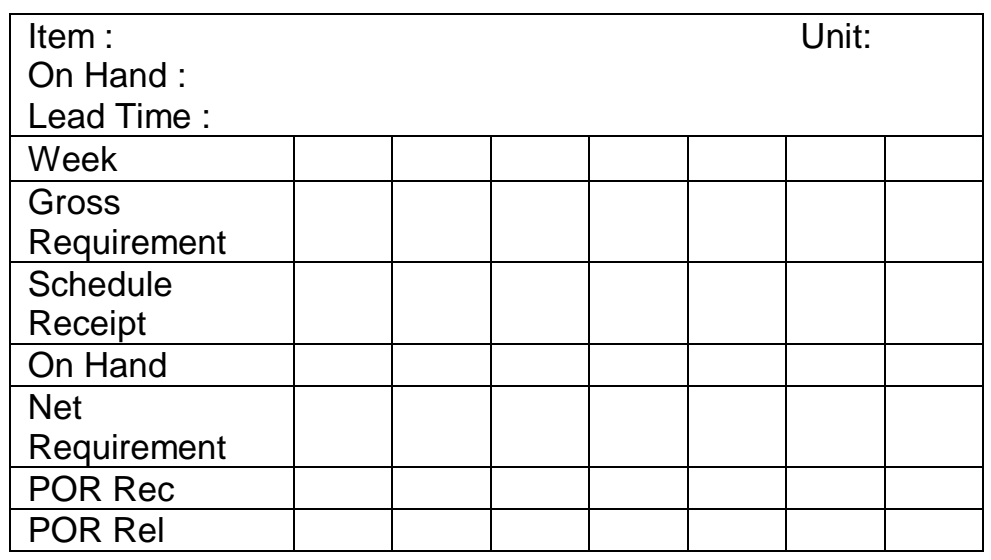

1) Gross Requirement: GR / Gross Requirement is all the total item / materials required within a certain period of time.

2) Schedule Receipt: Is the schedule of arrival/receiving the goods / materials ordered.

3) On Hand: Is total of the stock at the end of a period by calculating the existing stocks plus the materials that will be received.

4) Net Requirement: Is a net requisition of the items required to fulfil a rough requirement for a certain next period.

5) POR Rec: Planned Order Receipts Is total items that will be arriving which is in line with the purhase order.

6) POR Rel: Planned Order Release : Is total items planned to be ordered to cover the next planning. 


\section{Research Design}

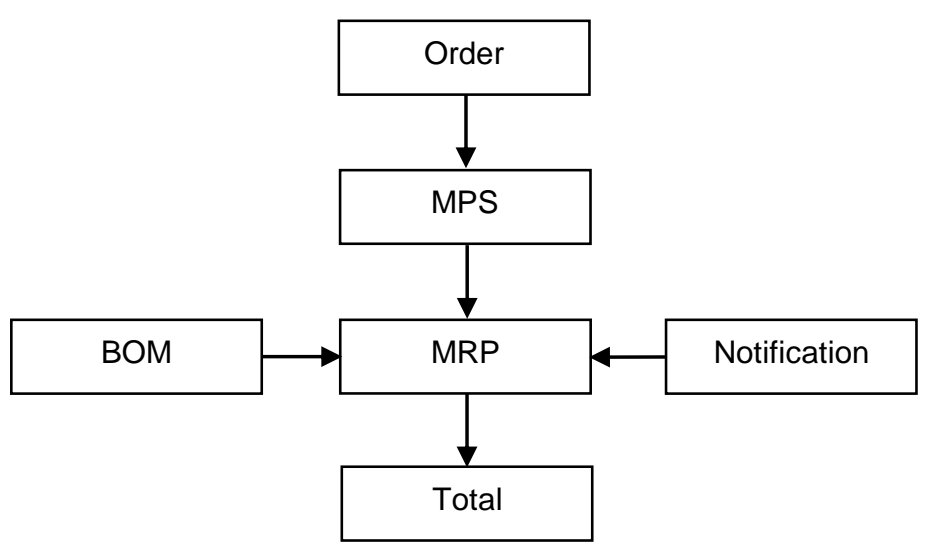

\section{Research Methodology}

\section{Research Methodology}

Data being used in this research is secondary data about raw materials consumption for Yogurt products in one year period (2015).

Research method has applied case studies at PT Heavely Nitrition Indonesia.

\section{Type of the research.}

This research has applied descriptive research describing the application of Material Requirement Planning technique to control the stock of raw materials at PT Heavently Nutrition Indonesia.

\section{Research Unit}

PT Heavenly Nutrition Indonesia is a manufacturing company dealing with food and beverages business producing food product and particularly yogurt drinks are well-known by the people.

In the production process, PT HNI is not only producing its own products, but also having toll manufacturing with other companies to produce some of the products.

PT HNI has produced varied finished goods starting having a long expiration date of yogurt drinks and fresh yogurt drinks. Producing the products, PT HNI has classified the products as follows:
a. Yogurt Drink $300 \mathrm{ml}$
b. Yogurt Drink $200 \mathrm{ml}$
c. Yogurt Drink $180 \mathrm{ml}$
d. Yogurt Greek $100 \mathrm{gr}$
e. Yogurt Bar $25 \mathrm{gr}$

\section{Method of Data Collection}

Method of data collection required for the analysis, the writer has applied documentation and secondary data, as follows:

a. Case Study

As to finish the related case in a quite short period, the data used is only production forecast year 2015 about total stock of raw materials, planning of raw materials purchase. 


\section{b. Library Review}

The method to get the information is from books, literatures and researches obtaining the information or data related to the stocks inventory and MRP method.

\section{Data Analysis Method}

Data Analysis Method has applied MRP method using the following steps:
a. To get the planning of production schedule (RJP).
b. To find out and to get the data of products structure or Bill of Materials (BOM).
c. To figure out the opening stock of 2015.
d. To figure out the production requirement of raw materials using the calculation of $\mathrm{RJP} \times \mathrm{BOM}=$ raw materials required by the production.
e. Based on the raw materials required by the production, it can prepare the output of the recapitulation of raw materials required by the production.
$\mathrm{f}$. Then, it can calculate the planning of gross total of raw materials required.
g. After having figured out the planning of gross total of raw materials and calculated with total of opening stock, it will obtain the planning of net raw materials required.
$\mathrm{h}$. Based on the data of the output of net raw materials required and calculated its lead time, planning of raw materials purchase will be depicted.
i. Based on the output of planning of raw materials purchase, it can show the cost of purchase by calculating each unit price of raw material item.

\section{Result Analysis of The Research}

\section{General Description}

PT Heavenly Nutrition Indonesia is a manufacturing company of food and beverages for diet and health purpose focusing to the milk processed product (yogurt) and other processed products. PT Heavenly Nutrition Indonesia was established legally on 24th June 2009.

\section{a. Mission}

PT Heavently Nutrition Indonesia mission is to provide deserts, light food and multi-vitamin drinks helping the people who want to maintain their healthy life especially when they are at home.

b. Value

The value of PT Heavenly Nutrition Indonesia is declared on the words "ICARE" All we do is starting from caring. Without caring, PT Heavenly Nutrition Indonesia is only getting the movement. Without caring, PT Heavenly Nutrition Indonesia will only be working on the brain instead of the heart. PT Heavenly Nutrition Indonesia has joined our logic with our heart and passion.

\section{Controlling System}

a. Procedure of raw material purchase requisition

Raw materials purchase requisition is provided by the PPIC (Production Planning and Inventory Control) calculating them based on monthly master production planning to define the quantity of raw materials ordered and to provide the production requirement for the next three months.

b. Procedure of Receiving Raw Materials.

The department of receiving goods in the warehouse will receive the raw materials sent by the suppliers based on the PO issued by the purchasing. 
c. Procedure of materials storage

After having the material released by QC (Quality Control), the material is sent to the warehouse attached with BBM, copy of delivery note and QC released lable.

d. Procedure of Raw Materials Distribution.

Procedure of Raw Materials Distribution is applied only based on the raw material purchase requisition refers to the standard quantity for one batch of the product and additional quantity of the raw material requested by $Q C$ and $R$ \& D for the purpose of retesting the raw materials.

\section{MRP Implementation}

a. Master Production Schedule

Master Production Schedule is the main factor performing the process of raw materials and production planning particularly using MRP method.

b. Bill of Material (BOM)

BOM is the materials composition producing the finished products which is the materials that are interdepending on each other.

c. Available Materials Stock

Stock of raw materials is one of the component required in the calculation using MRP, an accurate information and data of raw materials stock are very crucial in a company since stock of raw materials is required to make a decision about purchasing planning and production planning.

d. Outstanding Order

Outstanding order is one of the components of MRP calculation process. Outstanding order is named PO Outstanding which is the purchasing of raw materials that has been planned before and will be received according to the time schedule of materials arrival to fulfil the production requirement on the related month.

e. Leadtime

In the production process at PT Heavenly Nutrition Indonesia, leadtime has indicated the standard hour of the process based on the average of producing process and it is going to be reviewed every three months period to identify data accuracy. PT Heavenly Nutrition Indonesia has been producing on average 10,000 to 15,000 cups of yogurt daily.

\section{Monthly MRP Output}

a. Materials Requirement of Heavenly Blush Yogurt production.

Materials requirement of Heavenly Blush Yogurt production is one of the MRP output designing the quantity of raw materials required in a related month.

b. Production Recapitulation of Raw Materials Requirement.

Production recapitulation of raw materials requirement is one of MRP output designing the recapitulation of raw materials required by the production.

c. Planning of Gross Raw Materials Requirement

Planning of gross raw materials requirements is MRP output describing total quantity of raw materials requirement and the arrival date of the materials as well as their quantity ordered considering the the stock on hand (existing stock). 
d. Planning of Net Raw Materials Requirement

Planning of net raw materials requirement is MRP output describing the requirement of net raw materials and informing the arrival date and the quantity of the materials that should have to be ordered based on the stock on hand (existing raw materials availability).

e. Planning of the Raw Materials Purchase

Planning of the raw materials Purchase is MRP output describing when the materials will be arrived and quantity of raw materials that should have to be ordered by considering the lead time of the raw materials.

f. Quantity of Raw Materials Purchased

Quantity of raw materials purchased is MRP output describing the receiving date and quantity of raw materials purchased.

g. Cost of Raw Materials Purchased

Cost of raw materials purchased is MRP output describing the amount of cost spending in the process of raw materials purchased in a certain period of time (weekly / monthly)

h. Analysis of Raw Materials Inventory

Analysis or raw materials inventory is MRP output describing the quantity of raw materials that must be managed or stored in the warehouse every month and how much the cost that has to be spent by the company during the inventory storage in montly period.

\section{Yearly MRP Output}

a. Yearly Recapitulation of Raw Materials Required by the Production.

Yearly recapitulation of raw materials required by production is MRP output describing the recapitulation of raw materials required by yogurt products within a year.

b. Analysis of Yearly Raw Materials Inventory

Analysis of yearly raw materials inventory is MRP output describing the quantity of stock to be managed or stored in the warehouse in one year periode and how much the cost of storing has to be spent by the company during one year period of inventory storage.

c. Yearly Recapitulation of Planning the Purchasing of Raw Materials

Yearly recapitulation of raw materials purchased is MRP output describing the quantity of raw materials purchased within a year. Besides that, it is as a comparative data mentioned on the recapitulation data of raw materials purchased by PT Heavenly Nutrition Indonesia during 2016.

d. Recapitulation a yearly stock of raw materials

Recapitulation a yearly stock of raw materials is MRP output describing to what extent of the stocks are kept in the warehouse in a year.

e. Cost of Raw Materials Purchase

Cost of raw materials purchase is MRP output describing how much cost must be spent by the company for the process of raw material purchase within a year based on the standard cost price. 
f. Yearly Cost of the Inventory

Yearly cost of the inventory is MRP output describing to what extent the cost have to be paid by the company due to the process of inventory storage in a year based on the standard cost price.

\section{Conclusion and Suggestions}

\section{Conclusion}

a. Model of inventory control which has been done by PT Heavenly Nutrition Indonesia is an average calculation method during the last three months, and it is based on the forecast of marketing department requisition, nevertheless, the calculation for some products is using an average of historical periode which is the previous year in order to obtain the forecast of raw materials purchase.

b. Implementation the technique of Material Requirement Planning (MRP) has to be supported by important components as the following:

1) Clear Master Production Schedule (MPS).

2) Completeness of production structure.

3) Accurate inventory record.

4) Lead-time data for each raw material is identified starting from purchase order (PO) issuance till the using of raw materials involving incoming test released date by quality control.

Refering to the components above, after getting thru computerized calculation process the output of purchasing the raw materials is obtained, then, this output is moving to further process to perform inventory control in the company.

Cost Reduction Is Happened Due to Applying MRP Method

\begin{tabular}{|c|l|c|c|}
\hline NO & \multicolumn{1}{|c|}{$\begin{array}{c}\text { Cost } \\
\text { Reduction }\end{array}$} & Average & MRP \\
\hline 1 & $\begin{array}{l}\text { Reducing } \\
\text { selling price }\end{array}$ & $\sqrt{ }$ & $\sqrt{ }$ \\
\hline 2 & $\begin{array}{l}\text { Reducing } \\
\text { Inventory } \\
\text { Value }\end{array}$ & - & $\sqrt{ }$ \\
\hline 4 & $\begin{array}{l}\text { Reducing } \\
\text { storage cost }\end{array}$ & - & $\sqrt{ }$ \\
\hline 5 & $\begin{array}{l}\text { Efficiency } \\
\text { delivery cost }\end{array}$ & - & $\sqrt{ }$ \\
\hline
\end{tabular}

\section{Suggestions}

Based on the result of the research above, the writer has suggested PT Heavenly Nutrition Indonesia should have been working on the planning and inventory control using MRP method. Because MRP has proved making more efficient financial issue and more effective operational warehousing. Nevertheless, forecasting a planning is easier relating to the decision making circumstances.

Impact of using MRP has caused reducing cost of purchasing and cost of inventory comparing with common method using. 


\section{References}

Daft, R.L. (2012). Era Baru Manajemen. Buku 2. Jakarta: Salemba Empat. (New Era of the Management. Book 2.).

Gaspersz, V. (2012). All In One Management Tollbook. Jakarta: Gramedia Pustaka Utama.

Haming, H.M., Nurnajamuddin, H.M. (2011). Manajemen Produksi Modern: Operasi Manufaktur dan Jasa. Buku 1. Jakarta: Bumi Aksara. (Modern Production Management: Operation Manufacture and Service. Book 1).

Hanafi, M.M. (2010). Manajemen Keuangan. Edisi Pertama. Yogyakarta: BPFE. (Finance Management. First edition.).

Heizer, J., Render, B. (2009). Manajemen Operasi, Buku 1. Edisi 9. Jakarta: Salemba Empat. (Operation Management. Book 1).

(2010). Manajemen Operasi, Buku 2. Edisi 9. Jakarta: Salemba Empat. (Operation Management. Book 2).

Herjanto, E. (2011). Manajemen Operasi. Edisi 3. Jakarta: Gramedia Pustaka Utama. (Operation Management).

Nasution, A.H. (2008). Perencanaan dan Pengendalian Produksi. Yogyakarta: Graha Ilmu. (Planning and Production Control).

Sartono, A.R. (2010). Manajemen Keuangan Teori dan Aplikasi. Edisi 4. Yogyakarta: BPFE. (Finance Management, Theory and Application) 
The Management Journal of BINANIAGA Vol. 04, No. 01, June 2019 p-ISSN: 2527 - 4317, e-ISSN: $2580-149 x$

$6^{\text {th }}$ Accreditation Rating: April 04, 2019-April 03, 2024

This page intentionally be emptied.

Yustiana Wardhani and Ikbal Indrawan. Analysis of yogurt raw materials control using MRP method at PT. Heavenly Nutrition Indonesia 